much used in meteorology, but which seems capable of various useful applications.

In the diagram herewith, the line of ordinates measures mean temperatures of the first quarters at Greenwich, and the line of abscisse those at Chicago. The cross-lines represent averages : $39^{\circ} 7$ for Greenwich, $28^{\circ} \circ$ for Chicago ; and each dot, by its position, indicates the character of a winter (temperature of first quarter) at both places.

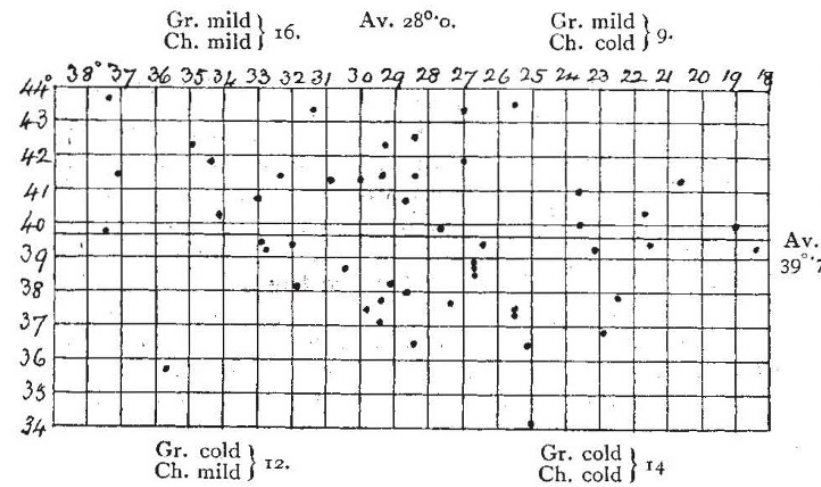

The vertical and horizontal scales being alike, one can see by the shape of the diagram how much greater are the variations of winter temperature at Chicago than at Greenwich.

If we call anything above the average mild, and anything below it cold, we find, on counting the dots in the four divisions, this state of things :-

Greenwich mild, Chicago mild Greenwich cold, Chicago cold Greenwich mild, Chicago cold

Greenwich cold, Chicago mild

Thus, 21 of those $5 \mathrm{I}$ first quarters (say 42 per cent.) were of opposite sign, and 30 of like sign.

The distribution of dots may suggest other points of interest, on which I need not here enlarge. It would be instructive, I think, to make other comparisons of the same kind. Some time ago Prof. Hann compared the winters (December-February) at Jakobshavn, in the west of. Greenland, and Vienna (Met. Zeits., March 1890, p. II2), and found a larger proportion of unlike signs than the above-viz. 27 cases, against 15 of like sign.

Alex. B. MacDowail.

\title{
DANTE AND THE ACTION OF LIGHT UPON PLANTS.
}

I $\mathrm{N}$ the history of vegetable physiology, sufficient importance has not been given to Dante's observations upon the action of solar light and heat upon plants, and to the ideas upon this action that existed in ltaly in the fourteenth century. Sachs, in his "Geschichte der Botanik," ignores Dante and Pier de' Crescenzi completely; observing in a general way: "Of the importance of Light and Heat for the nourishment and the growth of plants, next to nothing is to be found in the authors that wrote before the last decades of the seventeenth century; although certainly the action of these agents must have been known from the oldest times, in plant culture and in several special circumstances." 1 P. A. Saccardo also, in his "Primato degl' Italiani nella Botanica," does not take any notice of the observations and opinions of Dante and of Pier de' Crescenzi on light action.

In such special works as Ottaviano Targioni Tozzetti's "Cognizioni botaniche di Dante," written in 1820: R. de Visiani's "Accenni alle Scienze botaniche nella Divina Commedia," published in I 865 : and the quite recent book "Dante Georgico," in which, in a complete and able manner, Count Gastone di Mirafiore has collected all the

I Sachs, "Gesch. der Botanik," p. 387 ..

NO. I 53 I, VOL. 59]

references to agriculture, and to plants and animals, that are to-be found in the "Divina Commedia" and in the minor works of Dante: the historical importance of some of Dante's observations upon light action has been overlooked ; and no mention is made of the opinions prevalent upon this subject in Dante's time, as given especially by Pier de' Crescenzi. ${ }^{1}$

The best-known and often-quoted verses, in which the action of solar radiation upon plants is first noted in a modern language are those of "Purgatorio," xxv. 77 :

Guarda il calor del Sol che si fa vino Giunto all' unor che dalla vite cola ;

or, in Longfellow's translation :

Behold the Sun's heat which becometh wine Joined to the juice that from the vine distils.

Dante, despite his remarkable clear-sightedness in noting and describing natural phenomena, was not emancipated from what Whewell calls the commentatorial spirit of the Middle Ages; and these verses are but a powerful and poetical rendering of a passage in Cicero's "De Senectute," a book which, as may be gathered from the several quotations in the "Convivio," was much studied by Dante. There is no doubt, however, that Dante's verses have a special interest in the history of vegetable physiology ; for they drew attention to the importance of their meaning in two such master minds as Galileo and Francesco Redi.

It is not unlikely that the verses of Dante influenced Leonardo da Vinci in believing that "the sun giveth spirit and life to plants, and the soil with its moisture nourisheth them," ${ }^{2}$ leading him to an experiment in which the importance of leaf-function in the nourishment of plants is first noted, two hundred years before Malpighi. In this experiment Leonardo caused a water-fed plant to grow prosperously and bear fruit abundantly, although its roots had purposely been reduced to "only one tiny rootlet" (solamente una minima radice). Leonardo thus. succeeded in causing a plant to grow chiefly by its foliage, to "vivere della cima" ("Paradiso," xviii. 29): an experiment that would have been too dangerous for the experimenter in Dante's days. The "vivere della cima" was for Dante such a supernatural condition that it could only be described as possible for the symbolical tree of Heaven :

... the tree, whose life

Is from its top, whose fruit is ever fair, And leaf unwithering.

$$
\text { -Cary's Translation. }
$$

The verses of Dante on the action of sunlight on the vine are paraphrased in new verses in the "Bacco in Toscana "of Redi, the poet and naturalist, in describing the growth of wine, "that lovable blood":

Sì bel sangue è un raggio acceso

Di quel Sol, che in ciel vedete;

E rimase avvinto e preso

Di piu grappoli alla rete;

or, as rendered in English by C. H. D. Giglioli :

That blood so fine is a kindled ray

From the Sun, in heaven set,

Entangled and held a prey

By clustering grapes in their net.

Galileo, as Magalotti tells us, believed that "wine is a compound of light and sap." Magalotti rather diffusely

1 Ottav. Targioni Tozzetti, "Delle Cognizioni botaniche di Dante espresse nella Divina Commedia." Atti dell' Accad. della Crusca. Tomo ii. (Firenze, 1829.) Roberto de Visiani, "Accenni alle Scienze botaniche nella Divina Commedia" ; in "Dante e il Suo Secolo." (Firenze, 1865.) Gastone di Mirafiore, "Dante Georgico." (Firenze, r898.), See also: G. Bottagisio, "Osservaz. sopra la Fisica del Poema di Dante." Nuova ediz. sulla prima Veronese del 1807 , a cura di G. L. Passerini, Città di Castello, ${ }^{3} 894$. 1883.) 
dwells on Galileo's opinion. Starting from Castelli's explanation of how a black surface gets more heated in the sun than a white surface, Magalotti evidently believing the sun's action to be specially powerful on the vine, tries to show how light, "that last subtle impalpable dust of bodies," must be especially entrapped by the ripening grapes, and thus become the cause of fermentation and of the strength and aroma of wine. ${ }^{1}$ Giuseppe Del Papa, also a contemporary of Redi, one of the first to experiment on vinous fermentation, and to attempt measuring the heat developed in this process, was also of opinion (and he quotes the authority of I)ante), that "both oil and wine "are formed by the action of solar light and heat upon the water contained in plants. Del Papa describes the highly penetrative action of light: "So subtle that it penetrates in every part of our body without causing sensation; but only by acting inside the eyes does light awaken that feeling which we call sight." ${ }^{2}$

Indeed, Newton's theory confirmed the opınion that light may enter into combination with matter. And the action of light upon plants was accounted, before and after the experiments of Ingen Housz, by Lavoisier, Senebier, Carradori and others, as a fixing or combining of light in living vegetable substances, the green colouring matter being the first product of this combination. "Experiments made on vegetation lead us to believe that light gets combined with some part of the plant, and that to this combination are due the green colour of leaves, and the various colours of flowers . . ." Thus wrote Lavoisier in $1789 .^{3}$ Senebier, who in 1788 had already noted and experimented upon the antiseptic action of light, accounted for this action by believing that light became in some way fixed upon the organic substances that are preserved from decomposition.

When heat and light were no longer regarded as due to corpuscular emission, but as caused by vibrations of the luminiferous ether, the Dantesque notion of the fixation of solar heat and light died away, or rather became transformed into the notion of the storing up of energy.

An original observation by Dante is that light is the cause not only of the production of the green colouring matter of plants, but also of its decoloration. In a similitude describing the rise and wane of worldly fame, Dante writes ("Purg.," xi. I I 5) :

La vostra nominanza è color d' erba,

Che viene e va; e quei la discolora,

Per cui ell 'esce della terra acerba ;

or, in H. T. Cary's translation :

\section{Your renown}

Is as the herb, whose hue doth come and go ;

And his might withers it, by whom it sprang

Crude from the lap of earth.

It has been of course a matter of ancient and common observation that the green of vegetation is produced through the action of the sun, and that the sun withers up all vegetation, causing it to fade and dry. But Dante is the first to express the double action of light on the green colouring matter, causing both the production and the bleaching of the "color d" erba." One fancies him observing the rapid bleaching of green seaweed and of other fresh vegetable matter in the sunlight, and distinguishing between the discolouring and the shrivelling action of the solar rays.

I L. Magalotti, "Lettere Scientifiche ed Erudite" (Venezia, 1740), Lettera v. See also Redi's observations in 1686 on this letter: F. Redi, "Opere. (Napoli, 1778), Tomo v. p. 134.

2 Gius. Del Papa. "Trattati varî fatti in diverse Occasioni" (Firenze, 1734), p. 58; and "Della Natura dell' Umido e del Secco(Firenze, 169o) 1734), p. 58; and Della Natura dell Umido e del Secco(Firenze, 1690),
p. 174 .

p. ${ }_{3}^{174 .}$ Lavoisier, "Traité de Chimie, présenté dans un ordre nouveau et d'après les découvertes modernes" (Paris, 1789), i. p. 20r.

4 J. Senebier, "Exp. sur l'Action de la Lumière Solaire" (Genève, r788), p. 442.

NO. 153 I, VOL. 59]
We must come down to 1686 , to find again observations on the action of light on the production of the green colouring matter in plants. John Ray then distinguished between the heat-action and the light-action of the solar rays, observing that the colouring of foliage cannot be due to heat, often greater in closed dark spaces than in the open, but to the light of the sun. ${ }^{1}$

No exact observation upon the properties of the green colouring matter of plants could be made before a way was found of extracting the colouring principle from the vegetable tissues. This was first done, using alcohol and ether, by the two brothers Guillaume and Hilaire Rouelle, towards the middle of the eighteenth century; Hilaire Rouelle, the younger brother, published a note on the subject in 1773, remarking on the unstable properties of the green extract of plants. In I 782, Senebier had already shown that the decoloration of this green extract, prepared either with alcohol, or ether, or essential oils, is due to the action of light, and not of heat, and that the disappearing of the green colour is connected with a process of oxidation. The first experiments on the decomposition of the green colouring matter in the living plant are due to Gioacchino Carradori, in $1809 .{ }^{2}$ Thus the observation of Dante, in the beginning of the fourteenth century, on the double action of light in producing and decomposing the green colouring matter in living plants, forestalls a discovery that was made in our century ; and that has been further extended by the recent researches of N. Pringsheim.

Dante connected in a special way the vegetable activity of plants with the green of their foliage; and the effect of the specific virtue of the soul upon the body is compared to the green of leaves, the effect of vegetable life :

Come per verdi fronde in pianta vita ${ }^{3}$

And Dante observes that the discolouring of leaves is the sign of sickness in plants, in the vine especially (already subject to many maladies in Dante's time, as Crescenzi teaches us), remarking that the vineyard

\section{Soon turns}

To wan and withered, if not tended well ;

well noting, in the word imbianca, the chlorotic change in the plant:
Che tosto imbianca, se il vignaio è reo. ${ }^{4}$

No one before Dante, nor for many centuries after Dante, has so well noticed the depressive effect upon vegetable life of defective sunlight and persistent rain, by which roots are made to rot in the drenched soil, while leaves become discoloured and fall, and fruit fails to reach maturity :

Ben fiorisce negli uomini il volere ;

Ma la pioggia continua converte

In bozzacchioni le susine vere ;

or, according to Cary :

The will in man

Bears goodly blossoms; but its ruddy promise

Is, by the dripping of perpetual rain,

Made mere abortion. ${ }^{5}$

The best comment upon the botany of these verses, not well rendered in the English version, is in the recent experiments of Julius Wiesner, on the effect of continual rain upon different kinds of plants.

The action of sunlight in causing flowers to "awake" and to open was especially remarked by Dante, for he

1 Joa. Raius, "Historia Plantarum," (Londini, r686), vol. i. libr. i. p. 15. 2 G. Carraduri, "Sopra la distruzione del color verde operata dalla luce in alcuni Vegetabili viventi," Giornale di Fisica di Brugnatelli, vol. iii.

r809. "Purg.," xviii. 54

"Paradiso," xii. 86 , Cary's translation

5 "Paradiso," xxvii. r24. Cary's Translation. 
forcibly describes these actions in different parts of his poem with well-known verses :

Quale i fioretti, dal notturno gelo

Chinati e chiusi, poi che il Sol gl' imbianca,

Si drizzan tutti aperti in loro stelo ${ }^{1}$

or, in Cary's translation :

As florets, by the frosty air of night

Bent down and clos'd, when day has blanch'd their leaves,

Rise all unfolded on their spiry stems.

And in "Paradiso," xxii, 55 :

Così m' ha dilatata mia fidanza,

Come il Sol fa la rosa, quando aperta

or :

Tanto divien quant' ella ha di possanza ;

Have raised assurance in me : wakening it

Full-blossom'd in my bosom, as a rose

Before the sun, when the consummate flower

Has spread to utmost amplitude ;

and more forcibly still in "Purg.," xxxii. 54 :

Come le nostre piante, quando casca

Giù la gran luce mischiata con quella

Che raggia retro alla celeste lasca,

Turgide fansi ; e poi si rinnovella

Di suo color ciascuna, pria che il Sole

Giunga li suoi corsier sott' altra stella ;

but not so happily translated by Cary :

As when large floods of radiance from above

Stream, with that radiance mingled, which ascends

Next after setting of the scaly sign,

Our plants then burgein, and each wears anew

His wonted colours, ere the sun have yok'd

Beneath another star his flamy steeds.

The action of solar radiation in causing the rise of sap in plants, and in producing what nowadays we call vegetable transpiration, was especially noticed in the time of Dante, four hundred years before the experiments of Guettard.

Pier de' Crescenzi, the famous agricultural writer of Bologna, was a contemporary of Dante, and he lays special stress on the action of solar heat and light upon plants. Crescenzi's work, the "Opus Ruralium Commodorum," was written in I 305 , when the "Divina Commedia" was not yet finished, and when a part of the "Convivio" had not been written. Crescenzi's book, originally written in Latin, became so popular that in the lifetime of the author, or shortly after his death, it was translated into Italian; and since then, down to the beginning of this century, that book (it was among the first books printed, the first edition being of Strassburg, 1471) remained the standard agricultural encyclopæedia, republished in thirty Italian editions, and translated into the chief languages of Europe.

It is from Crescenzi that we gather best what Dante's ideas were on the action of light upon plants; and to Crescenzi we must look as the fountain-head of the ideas prevalent on that subject during many centuries. Crescenzi likened the vegetable to a man planted with his head downwards in the soil and all his limbs in the air. For the roots of a plant were considered the really vital part of the organism, its head and heart in one, by which, with many mouths, the roots sucked up with moisture the food prepared in the soil by the corruption of corruptible things. The soil was for plants what the stomach is to animals. Four hundred years later we still find Linnæus writing that plantarum ventriculus est terra. According to Crescenzi, not only is solar radiation the cause of the sucking-up action of vegetables, but also of the transformation and assimilation of plant food, separating the water with which it is mixed, the water being then transpired away.

$$
\text { NO. I } 53 \text { I, VOL. 59] }
$$

Thus Crescenzi finds that the growth and ramifying of plants is due to two causes : nourishment from the soil and the action of sunlight: "Branches ... multiply for two reasons: one of which is material, namely the abundance of nourishment; and the other is efficient, that is the heat of the sun, which on all sides toucheth the tree, and causeth the sap to boil up, and draweth it forth ; and therefore many branches shoot outwards in the upper parts, where the sap is more straitened, and is rendered more subtle by digestion. And the true proof of this is that plants which are surrounded by many other plants, as happens with trees in thick and shady woods, grow high, and do not produce many branches, nor are their trunks thick, and they have a certain lack and feebleness of branches; for, by want of sun, their sap is not drawn forth, nor does it boil at their outer extremities; for the coldness of the shade keeps in the heat which being constrained inside, fleeing from its contrary, sendeth on high all the nourishment." 1

"... The sap is a humour which, through the pores of the roots is attracted to nourish all the plant, and by its nourishing power gets distributed in all the parts of the plant; and it is necessary that it should be changed to the similitude of the plant by digestive heat."

". . . the nourishing humour of plants is more insipid when in the root, but as it goeth farther and farther from the root, the more it gaineth in taste convenient to the plant; and in the same way as it gaineth in savour, so doth it gain in density and in subtlety and in acidity; for by the action of heat these changes must occur. ..."

". . . because fruits require much power of the sun, leaves are placed somewhat distant from the fruits, so that these be not in the shade, and the digestion be not prevented that is done by the sun." 3

". . . the sun's heat giveth, as it were, perfection and form, and nearly giveth life ; for this reason moisture is formed in plants continually." 4

The hardening influence of light upon vegetable tissues, and the favouring of growth by heat in the absence of light are, for the first time in the history of plant life, noticed by Crescenzi, who thus shows that he formed some idea of the distinct action upon plants of heat and light: "Plants in warm weather grow in the darkness of night; and in the heat of the sun they harden and become woody." 5 This is a precise and simple statement of facts, without any reference to the action of the moon, as we find in later writers, such as Levinus Lemnius, the celebrated Dutch doctor, in his curious book, "De Occultis Naturæ Miraculis," published in $1559 .^{6}$

It is by Carradori, at the beginning of this century, that we again find stress laid on the action of light in giving robustness and hardness to vegetable tissues. Indeed, the words of Crescenzi may be paraphrased with those of the most eminent writer on the physiology of plants of our own times: "So far as plants are concerned, warmth chiefly signifies growth; while light, on the other hand, brings about nutrition." 7

Even as late as Liebig sufficient importance was not given to the action of light in hardening growing tissues; and only the experiments of Sachs and of Ludwig Koch have explained to us the reason why thick seeding, or a luxuriant vegetation, is followed by the laying of wheat and other high grasses.

It is evident that in the days of Dante a new spirit of inquiry was beginning, regarding not only the life of

1 Per de Crescenzi, "Trattato dell' Agricoltura," libr. ii. cap. 5.

2 Id., libr. ii. cap. 4. $\quad 3$ Id., libr. ii. cap. 6.

4 Id., libr. ii. cap. 25. 6 Lemnius writes: moved by the heat of the sun; and by night this food is diffused so that the food getteth increase ... by day, by virtue of the sun, all things ripen; and by night, by virtue of the moon, they are filled with humour and get swollen.

7 Julius v. Sachs, "Lectures on the Physiology of Plants," trans. by H. Marshall Ward (Oxford, 1887 ), p. 198. 
plants and the action of sunlight, but all natural phenomena. It would seem as if there were other than a purely theological meaning in the words by which Virgil, the master of the ancient knowledge, emancipates Dante from old learning and art, and opens to him the gates of new knowledge by admonishing him to look for himself; look to the sun shining before him, and to all the plants and trees growing spontaneously around:

... Lo tuo piacere omai prendi per duce ;

Fuor sei dell' erte vie, fuor sei dell' arte.

Vedi là il Sol che in fronte ti riluce;

Vedi l' erbetta, i fiori e gli arboscelli,

Che qui la terra sol da sè produce.

Non aspettar mio dir più, nè mio cenno :

Libero, sano e dritto è tuo arbitrio,

$\mathrm{E}$ fallo forra non fare a suo senno ;

Perch' io te sopra te corono e mitrio ; ${ }^{1}$

or, in Wright's rendering :

Take thou thy pleasure for thine escort now-

Forth of the steep and narrow way emerged.

Behold the sun upon thy forehead thrown-

Behold the trees, the flowers, of every hue,

In this most happy soil spontaneous sown.

No more from me expect or sign or word :

Thy will henceforth is upright, free, and sound :

To slight its impulse were a sin : then lord

Be o'er thyself; - - be mitred, and be crowned.

The splendour of the ancient literatures, dawning again upon Italy, overpowered the rising of the new science. The generations that followed Dante became more erudite than learned; and the new knowledge slept again through the centuries, just showing life with Leonardo da Vinci, and a few others, until the "unlocking of the gates of sense, and the kindling of a greater natural light," in the days of Bacon and Galileo. ITALO GIGLIOLI.

\section{THE REV. W. COLENSO, F.R.S.}

$W^{\top E}$ briefly announced in our issue of February I6 the death of the Rev. William Colenso, F.R.S., of Napier, New Zealand. The close of so interesting a life, which for more than half a century has been intimately associated with the progress of science and education in the antipodes, is one that demands more than a passing reference in the columns of NATURE.

Mr. Colenso was the son of the late S. M. Colenso, a saddler of Penzance, and was born in that town in I8II. He was put to learn the arts of printing and bookbinding in London, where he was eventually employed for a time on behalf of the British and Foreign Bible Society. In I833 the Church Missionary Society determined to establish a printing press in the then almost terra incognita of New Zealand. Mr. Colenso was selected to take charge of the enterprise, with results that must have more than justified the most sanguine expectations. An account of his early experiences in the joint capacity of printer and missionary was published by him in 1888 , under the title of "Fifty Years ago in New Zealand," and a more interesting history of pioneer work of the kind undertaken by Mr. Colenso, performed as it was under exceptionally unfavourable conditions, it would probably be impossible to find. "In December I837," says the technical journal Typo (April 26, I890), "under difficulties such as perhaps no printer ever had to surmount since the first invention of the art, Mr. Colenso completed his great work (a translation into Maori of)the entire New Testament, in octavo, small pica type." From about the year I840 Mr. Colenso devoted himself

$$
1 \text { “Purgatorio," xxvii. 131. }
$$

NO. I 53 I, VOL. 59] principally to mission work. In 1844 he took orders, after preparation under Bishop Selwyn. In the same year he settled at Hawkes Bay, where he resided for the rest of his life.

An ardent lover and student of nature, Mr. Colenso has left behind him a distinguished record as a botanist and as an authority upon the natural history of the archipelago. For his services to botanical science he was in 1886 elected a Fellow of the Royal Society, having been previously made a Fellow of the Linnean Society. The wild woods and mountains of his island home, traversed unremittingly by him in his missionary avocations, exercised throughout his life an ever-increasing fascination on his mind. With the Maoris his acquaintance was necessarily of a most intimate character; and he became an authority second to none on the subject of their language, arts, and legendary lore.

On June 25 , I 896 , a notice appeared in NATURE of the generous scheme for the foundation of a museum that Mr. Colenso had put before a meeting of the Hawkes Bay Philosophical Institute. The enlightened spirit in which the scheme had been conceived is shown by the extract which we printed from Mr. Colenso's address to the meeting. In offering $1000 l$. as a nucleus of the fund required for the establishment of the museum, he imposed the condition, among others, that the museum should be opened on Sunday afternoons as well as on every weekday. It is stated in the Cornish press that the reception accorded to his munificent offer was very disappointing to him, and that the scheme was withdrawn by him in the following year, with the announcement that his books and money would go to his native town. He had already presented $1000 l$. to the borough of Penzance, the income from the investment of which sum is utilised for annual gifts to the deserving poor. At the end of 1898 this fund, known as the "Colenso Dole," was increased by a second donation of roool.

Mr. Colenso's zeal in the pursuit of science, and his enthusiasm for missionary work did not exhaust his energies. He discharged important public duties from time to time. In the days when the relations between the natives and the colonists were strained he acted as a negotiator in the interests of the Maoris, and was the last survivor of the English signatories of the treaty of Waitangi. He was a member for Napier in the first General Assembly, and retained the seat for many years.

Mr. Colenso was a first cousin of the late Bishop of Natal. There are marked points of resemblance between the spheres in which the two men worked, and it is not surprising that the former felt himself to be in close sympathy with his South African namesake on the subjects which the Bishop had at heart.

This fact, and the untiring energy which sustained Mr. Colenso in his latest years, are evidenced by the following extracts from a letter which he wrote to a correspondent in London barely two years ago. He said: "I am leaving here to-morrow morning by rail for the Bush district (that is the forest country) in the interior, having Church duty at Woodville, IOo miles S., on Sunday next, the Vicar being unwell. Last Sunday I took Church duty here at St. Augustine's, and on the Sunday before at Clive, a village nine miles E. towards Cape Kidnappers. I am far too old (eighty-six) to undertake the duties of a parish, but I love my zork, and am always ready to help as far as I am able." He then adds that he had always been "a great admirer and supporter" of Bishop Colenso's "theological works." "I have them here," he writes, "and have often studied them. I particularly like his volumes of Natal sermons, \&c., and went with him wholly in the matter of the oppressed and ill-used Zulus."

It is greatly to be hoped that the preparation of a biography of this remarkable man may fall into thoroughly competent hands. 